\title{
The Impact of the Job Stress, Job Autonomy and Working Conditions on Employee Satisfaction
}

\author{
Muhammad Rizwan \\ Lecturer, Department of Management Sciences \\ The Islamia University of Bahawalpur (Pakistan) \\ rizwan.arshad@iub.edu.pk
}

Muhammad Imran Jamil

Department of Management Sciences, The Islamia University of Bahawalpur (Pakistan)

mijami10700@gmail.com

Umar Shahid, Akhtar Saeedi, Nabeel Faisal, Zohaib ul Islam, Ahad Qadeer, Abdul Mateen

Department of Management Sciences, The Islamia University of Bahawalpur (Pakistan)

Doi:10.5296/ ijhrs.v4i2.5907ＵRL: http://dx.doi.org/10.5296/ ijhrs.v4i2.5907

\begin{abstract}
This paper elaborates a comprehensive judgment of employee satisfaction indices of business, the factors resulting the displeasure \& suggestions to improve them. Satisfaction of human reserve result the close relations to very much-motivated Human Resources (HR). Additionally, little levels of employee satisfaction were associated to negative work actions and motivations. There is a great concern about the employee satisfaction and their involvement among employees is having the opportunity to use their efforts and skills at work. Employees commonly have skills and efforts beyond the place for which they were hired. The study investigates the special effects of job stress, working conditions and job autonomy on employee satisfaction. The quantitative data was collected from the industrial sector and private banking scatter (Financial institutions) of the Punjab (Bahawalpur) that consists of a sample size of 180 including the administrative, accounts and finance. The suitable sampling technique was used to collect the data from the target population. The 160 questionnaires were circulated in the administrative, accounts and finance. For analysis, we have used regression analysis techniques. The results showed that job stress has a relationship with employee satisfaction. Job autonomy \& Working conditions has also positive impact on employee satisfaction. These factors determine the satisfaction of the employee. In our opinion if the company is able to develop the desired facilities for their employees, then they
\end{abstract}


can perform better.

Keywords: Employee Satisfaction, Job Stress, Job Autonomy, Working Conditions

\section{Introduction}

The main issue of this study is to locate the main effective elements which are not only defining the job satisfaction but also help out the problem which the employees face during their work. When there are impressive varying surroundings, then most important contribution of the organization to motive as well as satisfied their employees in order to gain competitive benefits. Therefore, this examine was mainly work to explore on the implication of factors such as working conditions, job stress and job autonomy in moving the Employee satisfaction. Markow and Klenke (2005) and Milliman et al. (2003) states that the satisfying behavior and character of working direction can increase the organizational productivity and job satisfaction of the employee. Here, the major concerns about the employee satisfaction to point out the factors that are directly or indirectly influence the employee satisfaction. So higher the level of satisfaction of employee the greater the outcome of the organization productivity.

This paper elaborates a complete judgment of employee satisfaction indices of business, the factors resulting the displeasure \& suggestions to improve them. Satisfaction of human reserve result the close relations to very much-motivated Human Resources (HR). Additionally, little levels of employee satisfaction were associated to negative work actions and motivations.

When there is close relationship of employee satisfaction and the organization productivity, then the organization must consider such factors that determine the smooth outcomes. According to the Aydin and Ceylan, (2009), encouraging management style creates fervor among employees to accomplish the goals with honesty and it leads to satisfaction among employees. When the employees show out the positive obligation about their job in the firm this means that, there is high level of motivation and higher the productivity.

There is a great concern about the employee satisfaction and their involvement among employees is having the opportunity to use their efforts and skills at work. Employees commonly have skills and efforts beyond the place for which they were hired. Good individual who perform organizational practices also play a very important role in increasing the employees satisfaction on their job ( Bloom \& Van Reenen, 2007; Petrescu \& Simmons, 2008). Human Resource professionals can help their organizations guide and support their employees to load positions that involve greater-level skills. When there is the higher level of motivation of employees about their job with their employer then they do their best for the greatest of organization. In this way, organization always tries to find out the way in which they satisfied their employees.

Employee satisfaction refers to the amount to which the working surroundings meets the requirements and the wishes of the employees. The aim is to inspire latest behavior of 
working to develop labour output and to make major charge reserves without dropping employee satisfaction. Togia et al. (2004) proposed that the employee satisfaction is the main concern in which the employees satisfied their job.

According to the Seo et al. (2004), that there are many factors which is affecting the employee satisfaction of active such as organizational work stress, autonomy, and work load etc, psychosocial (pessimistic and optimistic liking), and environmental (employment types) were initiate. The employee satisfaction is one of the main internal factor which define the actual benefit for the organization, for both inside and outside. It also concluded (Le'vy-Garboua et al., 2007) that the relationship between prospect opportunity of own job and look in the future outside opportunities. In all that means that the policy makers and the managers must have pay more attention and concentrations about their employee satisfaction which result the higher level of productivity for the organization as well as the smooth running business for different environments. This description conclude that a association between the actual practice of job in the past and the intellectual practice of outside organization opportunities until then.

Many internal and external factors that can directly and indirectly affect the employee satisfaction and these factors varying according to the environment and change time to time. The Society for Human Resource Management (SHRM) has been show out its employee satisfaction inspection, there has been a clear variation in employees' overall satisfaction with their employees. Employee satisfaction is a significant up-and-down that is able to give an estimation about general sensation and thoughts forms of employees about their job and workplace. All it means that the workplace are the place where the employee satisfaction groom but supporting activities must provide by the organization. Thus, employee satisfaction results to opportunity of the employee about the place of work and his attitudes promote his job.

\section{Literature Review}

In all that means that the policy makers and the managers must have pay more attention and concentrations on environment, their mental level and their authority. This means their employee satisfaction which result the higher level of productivity for the organization as well as the smooth running business for different environments. Good individual who perform organizational practices also play a very important role in increasing the employees satisfaction on their job ( Bloom \& Van Reenen, 2007; Petrescu \& Simmons, 2008). Employees commonly have skills and efforts beyond the place for which they were hired, so in this way the owner and policy maker of the organization must concentrate on required factors. This description conclude that a association between the actual practice of job in the past and the intellectual practice of outside organization opportunities until then.

\subsection{Job Stress}

In common, job stress refers to someone's response to anxious tension consequences from job environment. The main reason in which the employee satisfaction are not performing as well as they do, because the stress in their mind. job stress has opposed relationship with 
powerful message, managerial maintenance, basic rewards, guidance, equitable, associate support, organizational maintain for employees, belief in managerial skills and also the result the main administrator support.

According to the W. Colligan and M. Higgins (2010), that the stress there is stimulus for the human resource and motivate the employee in their productivity due to improved employee performance in organization, on the opposite side there is also a harmful result for the organization if the organizational employee are not perform according to organizational expectations. There is relationship in which the employees are performing their job not according to the requirements of the organization. Jamal (1984) states that as job stress enhance the level of job performance in the organization decline. He also state that job stress was much correlated to job satisfaction (Jamal and Baba, 2000; Younas et al., 2013; Rizwan et al., 2013).

It also concluded that several types of personalities might direct to persons internally selecting jobs, which normally have greater levels of stress and mental distraction. Many researchers have defined stress according to the employee satisfaction in different words such as, Kazmi, Amjad, and Khan (2008) have defined stress as "an alteration in one's material or mind's condition, in other words defined that the interruption or inequality from actually condition. So when there is high level stress and their mental condition are not according to their level of activity, results lower level of productivity for the organization.

H1: There is a significant negitive relationship between job stress and employee satisfaction.

\subsection{Job Autonomy}

Autonomy define three meaning in the literature that it is the accountability, authority and responsibility (Mrayyan, 2006). Job autonomy is likely to provide employees the freedom of power over how they carry out their task in the organization, which is likely to reduce emotional tense and mental stress, caused by necessary present certain emotions and enhance their generally satisfaction of employee in the organization. Ford and his colleagues (2003) state that satisfaction of employee in the organization was openly associated to their obligation to their organization.

Job autonomy in the organization can be define as 'a physical performance, or set of practices relating the allocation of responsibility and produce the chain of command so as to give employees greater than before decision-making power in respect to the implementation of their main work activities' [(Leach et al., 2003), p. 28].

Job autonomy was also some time not produce positive association with employee environment and their working ability in the organization. (Adebayo \& Ezeanya, 2010) and with turnover intentions (Kim \& Stoner, 2008). Their over-emotionality and strengthening of negative emotions may be produce result of anxiety's negative effects and their result produce low productivity (Mikulincer \& Shaver, 2007). 


\section{Macrothink}

International Journal of Human Resource Studies

ISSN 2162-3058

2014, Vol. 4, No. 2

H2: There is a significant positive relationship between job autonomy and employee satisfaction.

\subsection{Working Conditions}

The desired work in which the employees feels comfort because of their working conditions and their environment that work result expected return for the organization. According to the Baron and Greenberg (2003) the lack of the working conditions in the organization which direct influence the working ability of the employees which also result the low productivity for the organization. Robbins (2001) states that working conditions will control job satisfaction, as employees are affected with a relaxed material work surroundings. On the other hand this will provide a more positive level of employee satisfaction.

Galup, Klein and Jiang (2008) states that the good organizations make sure their employees' job satisfaction consider the fact that lower level job satisfaction can cripple an organization.According to the Coetzer and Rothmann (2006) the social interactions, working environment and the relationship define the actual performance of the employee. successful organizations should provide culture that enhance and motivate the employee's satisfaction (Bhatti \& Qureshi,2007).

Skills contain one's education, knowledge and the specialties towards his job, great effort includes level of interest toward acquiring his goal, and work surroundings in the organization and the degree to which the operational environment facilitates the employee in performing their job up to the standard (Kazmi, Amjad, and Khan, 2008).

H3: There is a significant positive relationship between working condition and employee satisfaction.

\subsection{Research Model}

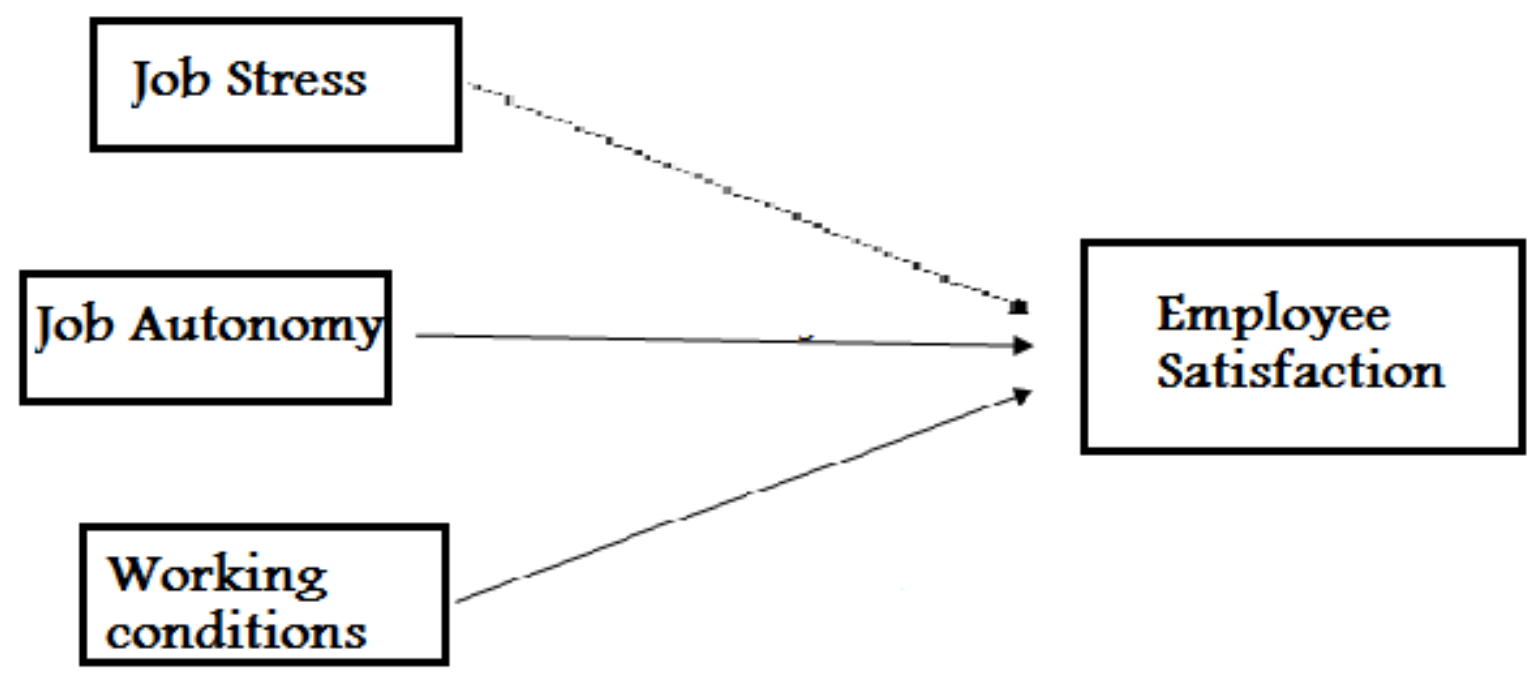




\section{Research Methodology}

This research nature is descriptive nature. Descriptive research can be defined as describing something, some phenomena or any specific situations. According to Creswell, (1994) descriptive researches defined the accessible situations instead of interpreting and making judgments .The major idea of the descriptive research is authentication of the developed hypotheses that image the existing situation. According to Kumar (2005), descriptive research provides information that consists about the existing situation and also focus on past attitudes and behaviors.

The study investigates the special effects of job stress, working conditions and job autonomy on employee satisfaction. The quantitative data was collected from the industrial sector and private banking scatter (Financial institutions) of the Punjab (Bahawalpur) that consists of a sample size of 180 including the administrative, accounts and finance staff from basic pay scale 7 to 19. The suitable sampling technique was used to collect the data from the target population. The 160 questionnaires were circulated in the administrative, accounts and finance and 160 were received, hence there was the $100 \%$ response received from the respondents. The questionnaire was use to measure the special effects of different factors on employee satisfaction supported by the literature review. The questionnaire section included the questions about job stress, working conditions and job autonomy. The questions of employee satisfaction were also integrated in the questionnaire. The questionnaires were distributed to the administrative, accounts and finance staff by hand. The Likert scale was used to get the answer indicating a score of 1 for strongly agree, 2 for agree, 3 for Neutral, 4 for disagree and 5 for strongly disagree.

It has ensured that the sample members posses the experience about their job and they must take active participation in their job related activity. They must be qualified about their work and be confidant about the situation which they handle about their job.

\subsection{Instruments and Measures}

The following instrument (questionnaire) was included which Employee satisfaction (Churchill et al., 1974) there are 07 items each scored on a five-point Likert-like scale. Job autonomy (Wang and Niemeyer, 2002) fixed choice questionnaire where respondents are asked to select the one best of two choices for each item. The Working conditions Sundstrom, E., etc. (1994), Konar, E., etc. (1982), Crouch, A. and Nimran, U.(1989) The questions in this section ask about employees work area; that is, the space surrounding employees in which they conduct most of their work. On a five-point Likert-like scale the Job Stress Tate et al. (1997) there is lower/higher score represents agree/disagree amount of job stress as perceived by the respondent.

\subsection{Procedure}

The quantitative data was collected from the industrial sector and private banking scatter (Financial institutions) of the Punjab (Bahawalpur) that consists of a sample size of 180 including the administrative, accounts and finance staff from basic pay scale 7 to 19 . The suitable sampling technique was used to collect the data from the target population. The 160 
questionnaires were circulated in the administrative, accounts and finance and 160 were received, hence there was the $100 \%$ response received from the respondents. The questionnaire was use to measure the special effects of different factors on employee satisfaction supported by the literature review. After collecting the completed questionnaires, these questionnaires coded and entered into SPSS sheet for further regression analysis.

\subsection{Reliability Analysis}

Overall cronbach alphas of all variables in our study are more than acceptable and recommended value is 0.50 by Nunnlly (1970) and 0.60 by Moss (1998). This shows that all the 26 items were reliable and valid to measure the opinions of employees towards their satisfaction.

Table 1: Reliability of measurements instrument

\begin{tabular}{|l|l|l|}
\hline Scales & Items & Cronbach alpha \\
\hline Employee Satisfaction & 7 & .694 \\
\hline Job Stress & 8 & .865 \\
\hline Job Autonomy & 5 & .831 \\
\hline Working Conditions & 6 & .680 \\
\hline
\end{tabular}

\section{Results And Analysis}

\subsection{Profile Of The Respondent}

Personal and demographic information such as gender, age, education and income of employees has given in (Table 2).

Table 2: $\quad$ profile of the Respondent

\begin{tabular}{|l|l|l|l|}
\hline Variable & Category & Frequency & Percentage \\
\hline Gender & Male & 112 & 72.3 \\
& Female & 43 & 27.7 \\
\hline
\end{tabular}




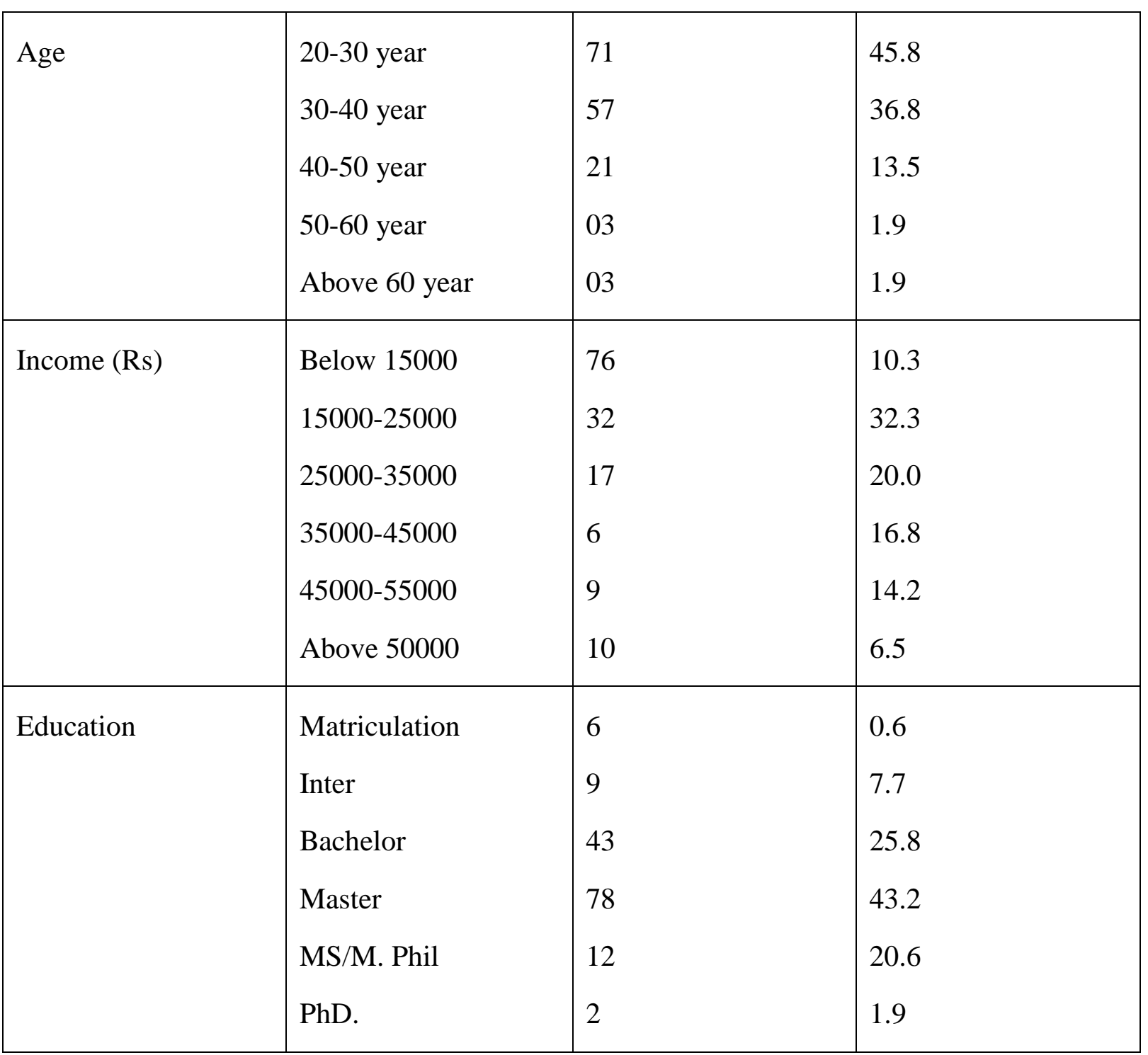

\subsection{Hypothesis Testing}

\subsubsection{Job Stress (JS) and Employee Satisfaction (ES)}

Consequently, this study explains that Job stress has a significant negative relationship with Employee Satisfaction. The job stress has relationship with Employee satisfaction $($ Beta $=-445)$ and $(p<0.01)$. That the above result shows that there is negative relationship between job stress and employee satisfaction. The regression results of the job stress confirm the H1.

\subsubsection{Job Autonomy (JA) and Employee satisfaction (ES)}

The results of the study validate that there is significant positive relationship between Job Autonomy and Employee Satisfaction with (beta=.305) and $(\mathrm{p}<0.01)$. According to these outcomes, Job Autonomy gives more than 30\% to Employee Satisfaction. These results validate $\mathrm{H} 2$. 


\section{Al Macrothink \\ International Journal of Human Resource Studies \\ ISSN 2162-3058 \\ 2014, Vol. 4, No. 2}

\subsubsection{Working Conditions (WC) and Employee Satisfaction (ES)}

The regression results of the study conform that there is significant positive relationship between Working Conditions and Employee Satisfaction with (beta=.011) and $(\mathrm{p}<0.01)$. According to these results Working Conditions contribute more than $11 \%$ to Employee Satisfaction. These results of the study confirm H3.

Table 3 summarizes the regression results of the study and figure 1 shows the graphical presentation of the structural model.

Table 3: $\quad$ Regression results

\begin{tabular}{|l|l|l|l|l|l|l|}
\hline Hypothesis & Model variable & Estimate & S.E. & $\mathbf{t}$ & $\mathbf{p}$ & Results \\
\hline H1 & JS $\longrightarrow$ ES & -.445 & .051 & -6.374 & .000 & Supported \\
\hline H2 & $\begin{array}{l}\text { JA } \\
\text { ES }\end{array}$ & .305 & .056 & 4.304 & .000 & Supported \\
\hline H3 & $\begin{array}{l}\text { WC } \\
\text { ES }\end{array}$ & .011 & .065 & .172 & .864 & Supported \\
\hline
\end{tabular}

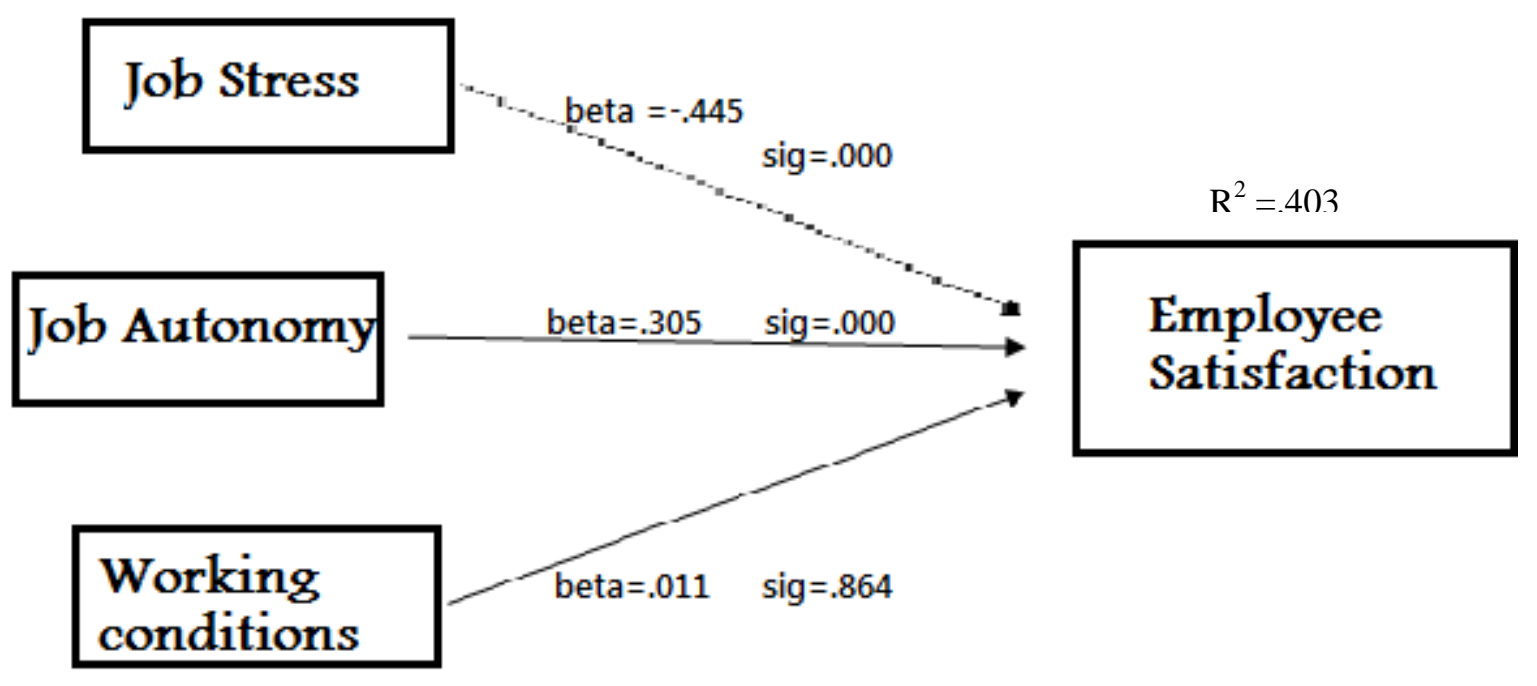




\section{Discussion And Conclusion}

When there is close relationship of employee satisfaction and the organization productivity, then the organization must consider such factors that determine the smooth outcomes. According to the Aydin and Ceylan, (2009), encouraging management style creates fervor among employees to accomplish the goals with honesty and it leads to satisfaction among employees. Satisfying behavior and character of working direction can increase the organizational productivity and job satisfaction of the employee. Here, the major concerns about the employee satisfaction to point out the factors that are directly or indirectly influence the employee satisfaction. So higher the level of satisfaction of employee the greater the outcome of the organization productivity. When the employees show out the positive obligation about their job in the firm this means that, there is high level of motivation and higher the productivity.

Good individual who perform organizational practices also play a very important role in increasing the employees satisfaction on their job ( Bloom \& Van Reenen, 2007; Petrescu \& Simmons, 2008). this research found how different employees accept management practices to exhibit stronger employee satisfaction. Employees commonly have skills and efforts beyond the place for which they were hired, so in this way the owner and policy maker of the organization must concentrate on required factors.

The stress there is stimulus for the human resource and motivate the employee in their productivity due to improved employee performance in organization, on the opposite side there is also a harmful result for the organization if the organizational employee are not perform according to organizational expectations. Employee satisfaction can develop service excellence and enhance employee satisfaction. In this condition, policy makers and managers have twisted their concentration to provide different kinds of services to their employees in order to persuade their employees. That is why the main purpose of this study, the experienced factors affecting employee satisfaction. The results recommend that the factors had agreeably explained employee satisfaction and that the policy makers and managers should focus on the factors that affect employee satisfaction, if they want to enhance their businesses.

The different factors which affect the employee satisfaction in order to gain organizational goals and enhance their productivity. Many factors that contributes the high and encourages support for the organization. the major concerns about the employee satisfaction to point out the factors that are directly or indirectly influence the employee satisfaction. So higher the level of satisfaction of employee the greater the outcome of the organization productivity.

\section{References}

Aydin, B., \& Ceylan, A. (2009). The effect of spiritual leadership on organizational learning capacity, Afr. J. Bus. Manage, 3 (5), 184 - 190.

Alegre, J., \& Chiva, R. (2007). Management of Technology and Innovation. Working Paper, 
retrieved May 27th, 2008,

Bhatti, K., \& Qureshi, T. (2007). Impact of employee participation on job satisfaction, employee commitment and employee productivity. International Review of Business Research Papers, 3(2), 54 - 68.

Coetzer, W., \& Rothmann, S. (2006). Occupational stress of employees in an insurance company. South African Journal of Business Management, 37(3), 29-39.

Ford, J.K., Weissbein, D.A., \& Plamondon, K.E. (2003). Distinguishing organizational from strategy commitment: Linking officers' commitment to job behaviors and satisfaction. Justice Quarterly, 20, 159-185.

Kim, H., \& Stoner, M. (2008). Burnout and turnover intention among social workers: Effects of role stress, job autonomy, and social support. Administration in Social Work, 32(3), 5-25.

Kazmi, R., Amjad, S., \& Khan, D. (2008). Occupational Stress and its effect on Job Performance: A case study of medical house officers of district Abbotabad. Journal of Ayub Medical College, 20(3), 135-139.

Rizwan, M., Shahzad, N., Sheikh, Q., Batool, S., Riaz, M. \& Saddique, S. (2013) Variables that Have an Impact on Employee Satisfaction And Turnover Intention, International Journal of Research in Commerce, Economics and Management, 3(3), 131-138

Younas, M., Rizwan, M., Khan, S., Majeed, Z., Khalid, S. \& Anjum, S. (2013) The Impact of Some Specific Factors on Employee Satisfaction: An Empirical Study from Pakistan. Journal of Basic and Applied Scientific Research, 3(12), 323-334

Lai Wan, H. (2007), "Human capital development policies: enhancing employees' satisfaction", Journal of European Industrial Training, Vol. 31 No. 4, pp. 297-322.

More, H. W., Wegener, W.F., Vito, G. F. \& Walsh, W.F. (2006) Organizational Behavior and

Management in Law Enforcement. Upper Saddle River, NJ: Prentice Hall.

Mire, S. M. (2005). Correlates of job satisfaction among police officers.(Doctoral Dissertation, Sam Houston State University, 2005). Retrieved

Markow, K., \& Klenke, K. (2005). The effects of Personal meaning and calling on Organizational Commitment: An empirical investigation of Spiritual Leadership, Int. J. Org. Ana. 13, 8 - 27.

Mikulincer, M., \& Shaver, P. R. (2007). Attachment in adulthood: Structure, dynamics, and change. New York, NY: Guilford Press.

Moss, S., Prosser, H., Costello, H., et al (1998) Reliability and validity of the PAS-ADD Checklist for detecting psychiatric disorders in adults with intellectual disability. Journal of Intellectual Disability Research, 42, 173- 183. 


\section{Macrothink}

International Journal of Human Resource Studies

ISSN 2162-3058

2014, Vol. 4, No. 2

Nunnally, J. (1970). Introduction to Psychological Measurement. Toronto: McGraw-Hill Inc

W. Colligan, T., \& M. Higgins, E. (2010). Workplace Stress: Etiology and Consequences. PERI Pakistan . 